\title{
THE INTERRELATIONSHIP OF RELIGION AND MAGIC IN THE EXPERIENCE OF LATVIANS IN TIMOFEYEVKA, SIBERIA
}

\author{
Aigars Lielbardis
}

\begin{abstract}
Groups of texts about seasonal celebrations, family customs and charmers are examined in this article in order to reveal the interrelationship of magic and religion in Latvian traditional culture in Timofeyevka. The recollections and knowledge of informants, recorded in 2004 and 2006, during fieldwork in Timofeyevka, have been supplemented with examples published in the 19th and 20 th centuries, as well as recently documented examples of Latvian folklore in Latvia.

The entire year of seasonal celebrations, which have become closely associated with the Catholic calendar - Christmas, Epiphany, Easter, Pentecost, Midsummer, and the remembrance of the dead in the autumn - has been examined. Annual festivities celebrated in the Latvian community have merged with Slavic festivals, for example, Easter, Pentecost and Midsummer traditions. In the recollections of family customs descriptions of funeral customs dominate over christenings and weddings. Notions of the supernatural are revealed in the stories of personal experience about healing, as well as in belief legends, which tell about the unusual ability of a person to transform into an animal or object. The experiences of the Latvian community of Timofeyevka concerning religion (official religion) and magic (unofficial religion) cannot be differentiated, because they represent a unified conceptual system in which one adds to the other.

The rich traditional cultural heritage in Timofeyevka has been preserved due to the location of the village far away from large cities and main roads, and also due to the Latvian community's large population numbers in the past.
\end{abstract}

Keywords: charming tradition, family customs, Latvians, magic, religion, seasonal celebrations, Siberia

\section{HISTORY AND PROBLEMS OF RESEARCH}

The study of Siberian Latvians was undertaken in the first half of the 20th century by Augusts Melnalksnis (1933, 1938), Vilberts Krasnais (1938) and Kārlis Šķilters (1928). Although during the Soviet era Latvians were forbidden to express any interest in Siberia, Ingvars Leitis, Uldis Briedis, Vaira Strautniece and Andris Slapiňš visited Latvian villages in Siberia in the 1970s, documenting evidence of Latvian culture and language. A study of another 
Latvian village, Nizhnaia (Lower) Bulanka (Lat. Lejas Bulāna), was published under the guidance of Vaira Strautniece in 1995. In 1996 and 1997, Roberts Kinlis conducted fieldwork in Bobrovka (Lat. Augšbebri) (Ḳilis 2002), which, like many other Latvian villages, was established at the end of the 19th century. In 2000, historian Jāzeps Brolišs published a historical-philosophical essay about the fates of Latgalians in Siberia (Brolišs 2000). Lidija Leikuma and Aleksejs Andronovs have been studying the language and history of Siberian Latgalians since 2004. Mikhail Kolotkins's study of Latgalians in Siberia was republished in 2012 (Kolotkin 2012). Still another Russian scholar, Ilia Lotkin, has also focused his interest on the ethnic processes of Latvians and Estonians in northern Siberia (Lotkin 1996). A number of these publications mention Timofeyevka village, although broader and more detailed information about this village was gained during the 2004 and 2006 fieldwork, which was undertaken by collaborating specialists from various fields - folkloristics, linguistics, ethnomusicology and history. A collection of academic articles about Latvians in Timofeyevka, which was based on the materials collected during this fieldwork and entitled Latvians about Latvians: Siberia. Timofeyevka, compiled by Aigars Lielbārdis, was published in 2011.

Today, Timofeyevka is a small village in the Vengerovsky district in Siberia, which is situated almost 500 kilometres from Novosibirsk, the regional centre. The village was founded in 1895 by emigrants from Latgale (the eastern part of today's Latvia), which belonged to the Vitebsk Gubernia of the Russian Empire in the 19th century. In the second half of the 19th century, Latvian emigration was stimulated mainly by political and economic factors - small farms, shortage of financial resources and land, as well as social and legal inequality. Latvian families, sometimes even whole villages, emigrated not only to other gubernias in Tsarist Russia, but also to other continents like Australia and North and South America. According to calculations made by Vilberts Krasnais, more than 200,000 Latvians, including Latgalians ${ }^{1}$, lived in the contemporary territories of Russia, Ukraine and Belarus, that is, in the Soviet Union in the 1920s (Krasnais 1938: 130).

In the early 20th century, Timofeyevka had already developed into a significant Latgalian centre in central Siberia. It appears that the villagers took about 10-15 years to adjust to their new living conditions and reach material prosperity: this assumption is based on the observations made by a Catholic priest Konstantīns Skrinda in the summer of 1909, when he and Archbishop Jānis Ceplaks travelled around Siberian Catholic communities. At that time, Timofeyevka already had its own dairy, church, 114 farmsteads and 540 inhabitants (Skrinda 1910). Later on, the village also boasted a mill and a butter factory. In terms of its population numbers, it was one of the largest Latvian 
emigrant centres in Siberia. Almost a hundred years later, in 2004, Timofeyevka had 170 inhabitants and only 66 of them identified themselves as being Latvian, and had good skills in the spoken Latvian dialect used in Timofeyevka (Mežs 2011: 73-74).

There was a church and a place for open religious worship in Timofeyevka until the late 1920s and early 1930s. As Soviet anti-religious campaigns became more active, an atheist group was established in 1928 (Skobajs 1928), and in 1933 a decision was taken to transform Timofeyevka church into a community hall - a club (Jurevičs \& Meikšans 1933). According to the recollections of villagers, the interior of the church was damaged and religious items were thrown into the nearby River Tartas. Nevertheless, people managed to rescue some of these objects and still keep them in their houses today, the broken details of crucifixes having been tied up with a ribbon.

Catholic prayer books and rosaries inherited from parents and grandparents are similarly treasured. Some women from the older generation still cross themselves after meals, saying thanks to God for the meal and also before lying down, to be safe while sleeping. This kind of religious piety is characteristic

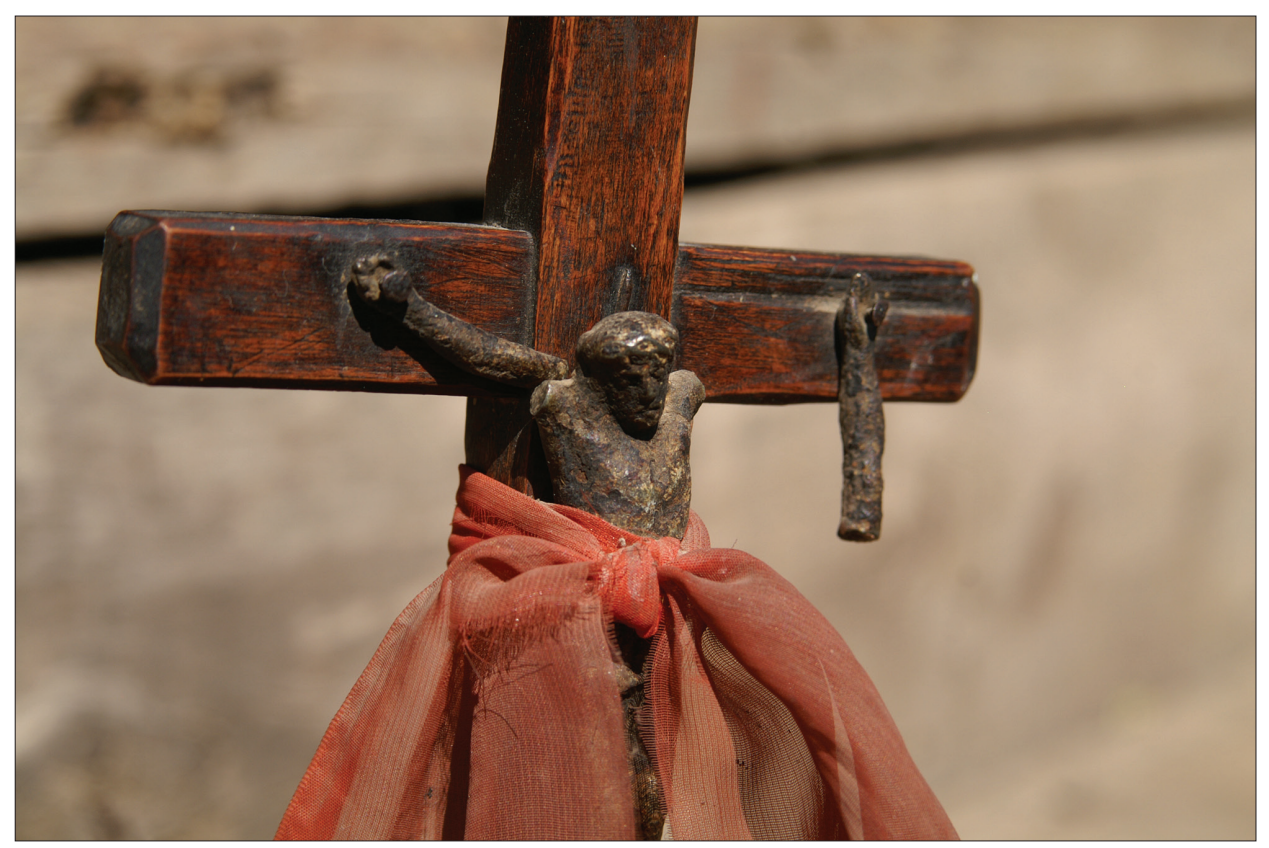

Figure 1. Broken crucifix at the home of Beña Vilcāne. Photograph by Janinna Kursìte 2006. 
of Catholicism generally, and was once taught and practiced within Latvian families in Timofeyevka, mostly due to the inner needs of individuals. Today, when both religious expression and the Latvian language are disappearing from active daily use, a strong link between language and denominational belonging still exists in the perceptions of the older generation in the Latvian community. At the turn of the 20th century, when national identity was strengthening in Latvia, people in Latgale often self-identified as Catholics. In Timofeyevka in 2004, an informant, Vera Kalugina, still expressed her doubt: "I am Latgalian... That is, a Catholic. Our Latvians are considered to be Catholics, not Latvians. Latvians speak some other language."

At the same time many respondents pointed out that there was no difference between Latvians and Latgalians. However, language and denominational belonging were listed as characteristics that distinguished Latvians from the Slavs and Tatars who also lived in the village.

Groups of texts about seasonal celebrations, family customs, belief legends and stories of personal experience, which characterised the activities of sorcerers and charmers, were used to discover the interrelation of magic and religion in the traditional culture of the Latvians of Timofeyevka. These groups of texts are independent, although they add to each other, and are closely intertwined in the mind of the user. The timing and content of seasonal celebrations are based on the passing down of societal customs, which include changes and influences between generations in farming management, as well as on isolation and detachment from the keepers of tradition in Latvia. Notions of the existence of the supernatural are revealed in the stories of personal experience in curing diseases and in belief legends that tell about the unusual ability to transform into an animal or object. In turn, family customs reveal the lifestyle and assumptions of the village community, which have occasionally gained new characteristics peculiar to Timofeyevka.

In his analysis of displays of magic, Latvian folklorist Kārlis Straubergs indicates that magic can be classified as either active (action, attempts to influence) or passive (knowledge of causal relationships in human life and nature) (Straubergs 1935-1936: 25147), and that "magic uses two main devices: words and action" (Straubergs 1923: 807). These devices are at the basis of both magic, which is commonly associated with folklore, and religious practice. Marcel Mauss has observed that magic, or a magical rite, is any rite that does not play a part in organised cults: it is private, secret, mysterious, and approaches the limit of a prohibited rite (Mauss 2006 [1972]: 30). Belief in supernatural forces, the knowledge of and attempt to influence them, are the grounds on which Catholicism and magic intersect and complement one another, and this is what has created the originality of tradition in Timofeyevka. 
In this article, recollections and knowledge recorded during interviews with informants in 2004 and 2006, during fieldwork in Timofeyevka, have been supplemented with published examples of Latvian folklore, in this way broadening the contextual information and offering comparative material.

\section{SEASONAL CELEBRATIONS}

These celebrations include annual events which, defined by the traditional way of life, have grown together with the Catholic Liturgical Calendar in Timofeyevka and can be evaluated not only in the context of contemporary Latgale, but also in the general Latvian context. Estonian folklorist Kristi Salve has noted that seasonal celebrations have three functions: (1) timekeeping, (2) magical, and (3) entertaining (Salve 1994: 160). Additionally, Latvian linguist and folklorist Beatrise Reidzāne has observed that the content of seasonal celebrations is based mainly on the same principles during both of the major celebrations of the year (Christmas and Midsummer Eve) and less important seasonal celebrations: (1) ritual activities and ritual prohibitions, (2) sacred meals, (3) fortune-telling and predicting (Reidzāne 2008: 233). Therefore, the presence of both religion and magic can be observed in the activities and interpretation of seasonal celebrations.

In Timofeyevka, seasonal celebrations in winter, spring and summer can be observed in the context of Latvia, while events in the autumn period are characteristic only of Latgale. In the autumn, a significant role is attributed to the honouring of the dead with psalm singing, or the Office of the Dead' ${ }^{2}$.

In earlier times, fir trees were decorated during Christmas in Timofeyevka, the priest visited people in their homes, and there was altar bread, decorated with pictures of Jesus. Both in Latgale and Timofeyevka, altar bread wafers were called kaladas, "holy bread that is made from wheat flour and is very thin - similar to a sheet of paper. The kaladas have various Christmas pictures. Before eating them you had to fast" (Čudare-Erina 2005: 144-145).

It was common for Latvians to go mumming at Christmas. Folklorist Jānis Alberts Jansons has observed that the word čigāni (Gypsies) designates those who participate in mummers' processions in all Latvian regions (Jansons 2010: 135). Informant Vera Loča states that, in earlier times, people in Timofeyevka went mumming at Christmas. Wherever they went, they were given something to drink and were offered a place at the table. They dressed up as old ladies and smeared themselves. Typical mummers' costumes in Timofeyevka were: a bear (a fur coat turned inside out), an old lady, and a devil (smeared in soot). When going mumming, special bags were taken along in which to pack the 
received treats. These kinds of bags were also used in mummer processions in Latgale both at the turn of the 20th century (Čudare-Erina 2005: 152), and in the late 20th century.

On Christmas Eve in Timofeyevka, just like the night before Easter, pious women came together, prayed to the Lord and sang religious songs. This type of night spent in prayers is called a vigil amongst Catholics. In the Soviet era, religious women held vigils secretly. The day before Christmas was called the $K \bar{u} c \check{a} a$ Day. The title is derived from the word $k \bar{u} \breve{c} a-$ a food that is made of barley, and is typically eaten during the winter solstice. The Küča Eve is known to Latvians, Lithuanians, Russians and Belarusians, both in terms of the name and similar functions (Līdeks 1991: 8), which indicates a wide distribution of the tradition and presumably also a shared heritage.

The Latvians of Timofeyevka were also familiar with fortune-telling at Christmas and during New Year celebrations. Informant Vera Loča recalls:

In earlier times, felt boots were tossed over the gate before Christmas and New Year. The direction in which they fell showed you where you would be married. They also went to the river for water. If you didn't meet anyone when coming back and you didn't hear anyone swearing, then you would get a good husband. But if you met someone who talked loudly or yelled when you were coming back from the river, then you would have a bad husband. If the person asked for a drink, then your husband would be a drunkard.

Fortune-telling by tossing footwear over a fence was also a familiar practice in Latvia (Līdeks 1991: 29), only the shoes that were thrown in Latvia were replaced by more wintery footwear in Timofeyevka - by felt boots.

Christmas is followed by Epiphany (Zvaigznes diena or Kreščine). On this day, crosses are drawn on the doors and doorposts. Informant Vala Savenko comments:

We always draw crosses on January 6. And we write 'Gaspar', 'Melchior' and 'Balthazar' on the doors. We cross the doors, windows, everything. We cross outdoors. Everywhere. The cows, calves, horses too-everything. So that everything goes well, so that no one gets sick. If not-they can get sick.

Epiphany is followed by Candlemas, Sveču diena or Gromnīca. In Latgale, candles are still blessed on this day. Vala Savenko tells us: "If the rooster has already been able to have a drink on this day, then it will be a bountiful year". An identical belief has been recorded in Riga: "If on Candlemas the rooster can have a drink under the roof, then it will be a bountiful year" (Šmits 1940-1941: 298040). 


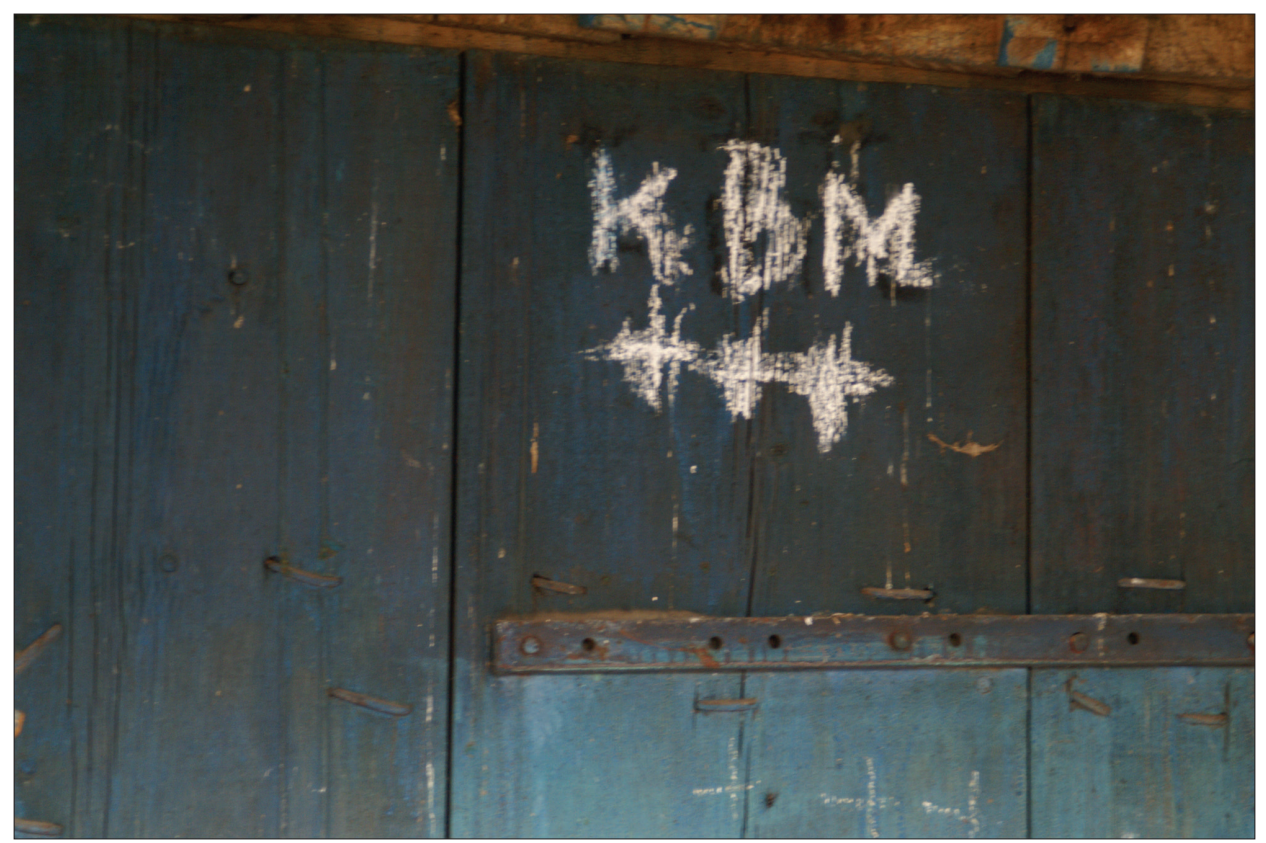

Figure 2. Crosses on the doors in Timofeyevka. Photograph by Janinna Kursìte 2006.

Candlemas is followed by Shrovetide (Aizgaveñni or Metenis), which is observed in Timofeyevka only as an activity of the past, by going horse riding and burning straw and hay on bonfires. Burning straw at Shrovetide and riding horses is also known to have been practiced all over Latvia (Līdeks 1991: 120-124). In Timofeyevka, the ancient name used in Latgale for this day, Aigavenni, has been preserved, alongside the Slavic Maslenica. This was the day before the beginning of Lent, or Gavēnis. Meat and fatty foods were not eaten during Lent.

Easter is one of the most richly described annual celebrations, because it continues to be celebrated in Timofeyevka today: eggs are coloured by boiling them in onion skins, and swings are hung. Children go from house to house. Entering each house, they say "Christ is risen!" three times, which must be answered with "Indeed he is risen!" The children are given pastries, sweets, or eggs. The custom of saying "Christ is risen!" in Russian has come from the Slavs, who gradually began moving into the village after the Second World War. In earlier times adults went from house to house and played egg tapping, and made swings on the bank of the River Tartas. 
In former times, and today as well, those of the Catholic faith spend the night before Easter and other celebrations at church (Čudare-Erina 2005: 163). During the Soviet period, when Timofeyevka did not have a church, these meetings were held at the home of one of the religious women. This was described by informant Gela Neminska, one of Timofeyevka's most prominent experts and singers of Catholic songs. Religious identity that is inherited and instilled from previous generations has found shelter in various religious cult objects. Vera Loča still treasures a prayer book and a rosary brought from Latvia, wrapped in a handkerchief. A small crucifix has been preserved from Timofeyevka church. Pussy willow and altar bread that have been blessed were brought for her from Novosibirsk. Vera Loča tells about how everyone in the household was symbolically 'flogged' with pussy willow on the morning of Palm Sunday, after which the branches were taken to church to be blessed. On Palm Sunday, whilst flogging, one recites:

Vierbu, vierbu!

Vierba syta, na es sytu.

Veseleiba vydā,

Slimeiba uorā!
Pussy willow, pussy willow!

The pussy willow hit, I didn't hit.

Health in the middle,

Sickness out!

Today no one flogs with pussy willow anymore. Pussy willow branches blessed on Palm Sunday were sometimes used to smoke out the place where the deceased had been laid in the home. The grave was also smoked with the pussy willow before the coffin was lowered. Blessed pussy willow was also given to domestic animals.

Pentecost (Vasarassvettki) in Timofeyevka is celebrated in the seventh week after Easter. It is the only time of the year when the inhabitants of Timofeyevka go to the cemetery to remember the dead. This is also an opportunity to meet relatives and the descendants of villagers whose family members are buried in the cemetery. Prayers are said, and food and glasses of vodka are placed on the graves when remembering the dead. The villagers themselves, and their guests, sit in a field by the cemetery and remember the dead while partaking in a meal. Pentecost, like Easter, has intertwined with the corresponding Slavic celebrations of Semik and Troica. During this time the Slavs remember the parents who have passed away (Fursova 2003: 7). Parallels can be seen between this tradition and Latvian cemetery celebrations, except for the fact that today the meal is not placed on the graves in Latvia. However, in the late 19th century, feasting in the cemetery was practiced in Latgale too: "[during the funeral] the family of the deceased treat the mourners by the graveside with beer, bread and cheese" (Ulanowska 1891: 209). The decoration of the house with 
birch boughs during Pentecost is typical both for Latvians (Šmits 1940-1941: 19606) and the people of Timofeyevka, and also the Slavs of the surrounding area (Fursova 2003: 9). In Latgale at Pentecost, shepherds decorated cows with birch branches and floral wreaths (Čudare-Erina 2005: 168). This was also practiced in Timofeyevka, and the shepherd was given an egg or a glass of vodka as a reward.

Although the older generation in Timofeyevka celebrates the summer solstice (Jāna diena or Jāñi) on June 24, it is celebrated in the village on July 6 as well. Similar to Pentecost, cows are also decorated on this day. Informants Vera Kalugina and Beņa Vilcāne recall that at Jāṇi it was customary to light bonfires, and to walk around the village, singing. People were given pastries and eggs for their singing. Cheese was also made, wreaths were plaited from wildflowers and beer was brewed at Jāni.

Fortunes were told on the summer solstice, as well as at Christmas, particularly amongst young women. Informant Zina Ivule remembers that they used to send wreaths down the river and watch where they floated: their future suitor was supposed to come from that direction. Fortune-telling with wreaths was also common in Latvia (Lìdeks 1991: 61).

Water held special meaning at Jāni : washing in the dew or in spring water, or taking horses for a swim at night helped to attain what was wished for beauty, health and success. Zina Ivule recalls:

How they splashed each other with water then! The minute you started splashing, the rain would come. Perhaps this celebration is from God. There's no rain, but then you splash, and a rain cloud starts to form. Even the adults would splash around. You splashed, and the rain always came. If there is no rain, then there will be no hay, no bread.

Splashing of water on this day was also known in Latvia (Jansons 1937: 7), although it was not very widely practiced. The influence of the Slavic surroundings can be observed here (Fursova 2003: 55). Some informants have replaced the title of Jāni with the Slavic Ivan Kupala. The night before Jāni is an active time for sorcerers and witches of both the Slavs and Latvians. In the region around Timofeyevka it was common for young people to gather together, search for witches and try to drive them away or do something bad to them. This tradition was widely practised in the Slavic villages near Timofeyevka (Fursova 2003: 62-63). Today this practice has transformed into entertainment for young people, with the aim of playing tricks on other villagers, for example, stealing their carts, wrecking their wood piles, etc. This kind of activity can also be observed in other Latvian villages in Siberia, for example, in Sukhonoi (Sukinava) (Lielbārdis 2007: 172). 
Latvian seasonal celebrations in the autumn are associated with the completion of farmwork and preparations for the winter. This is also a time of remembering the dead, or velu laiks (souls' time). In Timofeyevka, as also in Latgale, special events with psalm singing are organised to remember the dead - the Office of the Dead. The time for the commemoration of the dead is traditionally from Michaelmas (September 29) until Martinmas (November 10), but in some places it ends on All Souls' Day, November 2. The psalm singing tradition, established by Jesuit missionaries in the late 18th century, has been preserved in Timofeyevka as well as in Latgale (Lielbārdis \& Boiko 2012).

\section{FAMILY CUSTOMS}

There is a typical dominance of funeral traditions over wedding and christening customs in the recollections of the Latvians of Timofeyevka. Some informants mentioned that children would be christened by older women when there was no longer a priest in the village. The items brought to a christening included a bottle of alcohol and pastries, as well as clothes, diapers, and soap for gifts.

Wedding traditions were not emphasised either, justifying this by shortages of food and other products or the complicated post-war conditions. When attending a wedding, people took along a bottle of alcohol, as well as some meat, which was delivered a day or two beforehand. Beer was brewed for weddings. Zina Ivule tells us:

Beer was brewed, people celebrated. At weddings there was such singing! The bride was the subject of many sad songs, until she began to cry loudlyit was a valley of tears! During the wedding, horses were decorated, the shaft bow was wrapped in a beautiful towel and bells were attached.

The crying mentioned was brought about by special and purposeful singing to make the bride cry, which was an essential part of weddings in Latgale (Tihovskis 1993: 61).

Detailed information about funeral traditions in Timofeyevka is available in comparison. When a person dies, they are first washed with warm water and soap. The water is poured out at the gate by the northern (empty) corner, where no one walks, in order to protect one from illness or a malady, which can rise from the deceased. This cluster of beliefs was common throughout Latvia (Šmits 1940-1941: 1269-1272). After washing, the corpse is placed in another building, then carried to the main dwelling, where two chairs are placed, with boards on them, which are covered, and then the coffin is placed on top. The deceased is dressed in clean, usually dark clothes, with slippers on the feet. 
Women gather to say prayers, sing hymns and perform the Office of the Dead before the funeral and also on the day of the funeral. In Latgale, women also gather by the deceased in the evening, light a candle and sing songs, psalms and litanies (Ulanowska 1891: 208). As mentioned above, psalm singing is still encountered in Latgale today. In Latgale as well as in Timofeyevka, it is usually the women who specially practice this form of singing that are invited.

On the day of the funeral, the deceased is placed in the middle of the room. It is customary for the funeral to be held on the third day. The deceased is transported to the cemetery around $1 \mathrm{pm}$ or $1.30 \mathrm{pm}$, i.e., after lunch. Before transportation, the coffin is placed at the gates of the house for a short while, to bid farewell to the deceased. Earlier the coffin was transported by horse and cart, but today cars are used. There used to be a large crucifix at the edge of the village, where the funeral procession stopped for a moment. A wooden cross, $m \bar{u} c e n a$, was carried at the head of the funeral procession, followed by funeral wreaths. A man led the decorated horse by the bridle. A towel or a pair of mittens was hung on the mücena, which was given as a gift to the one carrying the cross. The grave diggers and coffin makers were given towels, while the woman who baked pastries was given a scarf. The coffin was carried behind the cross and wreaths, and after them came the mourners. In earlier times, hymns were sung at the cemetery. The lid of the coffin was opened at the cemetery, and later closed with two long nails. Informant Valentīna Bule jokes: "They hammer in big nails. After that, even if you want to get out, you can't."

Before the coffin was lowered, the grave was blessed: a page was ripped out of a prayer book and used to smoke out the grave. The smoking of the grave with blessed herbs before the deceased was lowered was also practiced in Latgale in the second half of the 19th century (Ulanowska 1891: 2009). As mentioned above, Vera Loča called the pussy willows that had been blessed in church on Palm Sunday blessed herbs. It is probable that the practice of smoking out the grave with the pages of a prayer book was a later development, which took place when it was no longer possible to bless pussy willows in church, that is, after the church in Timofeyevka was converted into a community hall.

In Timofeyevka, it is believed that if you meet someone on the road close to the village when transporting the deceased to the cemetery, there will be another death in the village soon, whereas if a person is met far from the village, death is further away. On returning from the cemetery, the mourners are given a meal. First, the women sit at the table, then the men, because men are the first to go to the sauna. The last ones to sit at the table are children. In earlier times, prayers were said before the meal, but this no longer happens.

A spiritual connection with the dead is still maintained long after the funeral, because memorial events are organised on the 9 th and 40 th day after the 


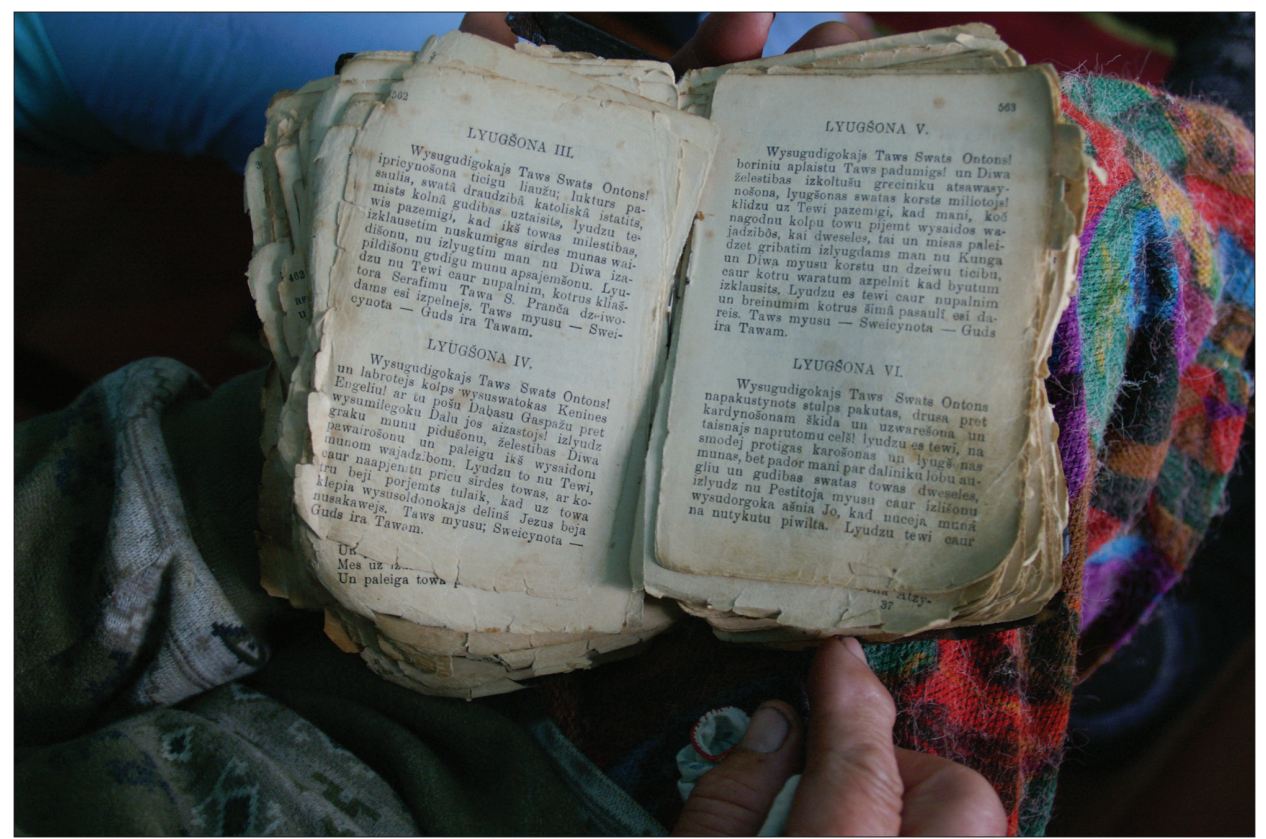

Figure 3. Zina Ivule's book of prayers and songs used for performing the Office of the Dead and for grave smoking. Photograph by Janina Kursìte 2006.

funeral. In earlier times, the Office of the Dead was performed on these days. Remembering the dead at the cemetery takes place during Pentecost, and they are also remembered at homes on the souls' day in the autumn.

The dead can communicate with the living also in dreams. For example, Gela Neminska tells us that if a dead relative appears in a dream, then someone from the family has to give a treat to the person who had the dream. Informant Viktoria Ruduša explains: if you have to give something to the deceased in a dream, then there will be a loss at home, or if the deceased appears in a dream, then one must pray for them as well, or one must feed the poor. If the deceased asks to be lifted out of the grave, then you must also pray for them. Zina Ivule also relates that if she sees someone dead in a dream, she says a prayer for the person. In Latgale today, if a dead person appears in a dream, it is interpreted as the deceased's need for something. Latvian ethnomusicologist Mārtin̄š Boiko, studying stories of meeting the dead in dreams, calls them request dreams (Boiko 2002: 119). These kinds of dreams are often the reason for the performance of the Office of the Dead at the home of the deceased. 
Sometimes dreams serve as a prediction of death. For example, Val,a Savenko tells us that if you dream of sprouted potatoes with small green leaves, someone will soon die. Dreaming of ploughing the garden is another bad omen - someone is going to die.

\section{CHARMING AND SORCERY}

Belief legends and stories of personal experience about charming, healing and sorcery in Timofeyevka fit into the Latgalian context, and that of Latvian folklore generally. It is supposed that the terms kolduns, čaraunīks (sorcerer) and varažot (to predict) as names for those who undertake various magical activities, are part of the inheritance brought from Latgale to Timofeyevka by the first settlers. Words of Latvian origin, which describe similar phenomena in Latvian folklore, are also used, although they have partly lost their meaning. For example, in Timofeyevka the word ragana (witch) is largely understood as a swear word.

In the village, healers who treated ailments and also sorcerers or witches (kolduni, čaraunīki) were usually women who had inherited their knowledge from previous generations. In earlier times, there were also midwives who attended births in Timofeyevka. Certain afflictions were well-known and regularly healed: erysipelas, toothaches and other pains, harm caused by the evil eye, dog and snake bites, hernias, broken bones and dislocations, children colic and colic in livestock. Healing methods included squashing and nipping (colic), tying wool (joint sprains), stroking (swelling), setting of dislocations, saying charms on water or spreadable healing substances. It was not possible to record the incantations during fieldwork, although it is known that hymns and the Lord's Prayer were used in Timofeyevka in the charms function. In 2006, there were two cartomancers in the village - Vera Ruduša and Vala Savenko. In turn, Galina Abaturina and Valentīna Jureviča, both Russians, worked as healers.

Healing is spoken about in the past tense, as there are no longer any Latvian charmers that can help others in the village. Informant Marija Vilcāne says:

There were these old women here. They could utter words to banish the pain. I had a broken arm. She uttered words, treated me, massaged me. She was called Vilku Gela. My husband's real aunt. She could say words when a snake had bitten you. She could charm a pain so that it wouldn't swell. It helped, it really helped. She spoke and stroked. She spoke the Latgalian God's songs. The songs were quite old. She whispered, spoke. Our father, who art in heaven... There were all sorts of words. 
Informant Vera Loča tells us that a snake bite can be treated both with words and without them - by squeezing the venom from the bite, scorching it, and applying sour milk. She treated her husband Jānis in this way. Another charmer had treated a snake bite by tracing around the bite with a special coin - a kopeck.

Snake bites in Siberian conditions were supposedly common and bites were only treated by older women. Each of the village charmers mentioned had treated a snake bite. Erysipelas, which was brought on by taking fright, was also quite common. Taking fright could also be a reason for a sickness called nobillis (affright) in Latvian, which was treated by pouring water over the patient in front of the stove. Colic ( $g r i \check{z} a$ ) could be healed with incantations. Small children usually suffered from colic. Informant Nina Kukule pointed out that you needed teeth with which the colic could be nipped. Nipping or pressing with fingers are methods that can be used to destroy other sickness - also colic, which often infects domestic animals.

Healing methods included soap with which corpses had been washed. If your hands hurt, or you had abscesses, then you washed your hands with it. The soap was also useful if your husband fought at home. Then you had to secretly give him this soap to wash his hands. Treatment with this kind of soap or other objects belonging to the world of the dead (a splinter from a cross, sand from a grave or a bone found in the cemetery) is a widely known healing method in Latvian folk medicine: the pain is symbolically transferred to the world of the dead.

During an interview, Valentīna Bule had a piece of white yarn tied around her arm, which she explained as follows:

My arm swelled up. It hurts. The bone, here. See, I tied this around, so that it would help the pain. It is said that the last one to be born in the house, the youngest, needs to tie it around. Now there's nothing. It seems that it no longer hurts.

It is best if the yarn is woollen, ideally of light colour and made of sheep's wool.

Considering the fact that there is no medical institution in Timofeyevka or in the vicinity - or that there has not been one previously - it is understandable that the villagers often deal with breaks and dislocations on their own. Marija Vilcāne told us about her mother-in-law, Domuse Vilcāne, who healed toothaches, and could also set dislocations. The words for healing were taken over from her by a Russian, Gaḷina Abaturina. Marija Vilcāne had visited her to treat a dog bite:

She can speak Latvian. I was in pain - a dog had bitten me. It really hurt. Everything was red, like erysipelas. I visited her. She uttered some words, and I spread something [given by healer Domuse] on it, and it was gone. 
As the author of this article was not successful in finding out the incantations used for healing, it is unknown whether the prayers and hymns used in incantations constituted just a part of them, or whether they made up the entirety of the charms. The Latvian tradition of charms encompasses both options: the text of the incantation may comprise only prayers, a bible text, or a fragment of a song; or the Lord's Prayer or invocation of the Holy Trinity may be added at the end of the charm.

In Timofeyevka, cartomancy (divination/fortune-telling with playing cards) is called varažošona. As linguist Jānis Zēvers points out, this word stems from Polish, with the definition 'to conjure' appearing in the catechism Mocieyba katoliszka published in Latgalian in 1775 (Zēvers 1925: 603). Cartomancy has two names in the language of the local villagers: varažot and godot. In 2006, there were two cartomancers in the village.

Sorcerers and sorcery in Timofeyevka are called kalduns and kaldavot, which means "to conjure, to do evil". Valentīna Bule tells us:

Sorcerers cast spells. Sometimes they cast spells so that a person becomes angry with another, and verbally abuses them. And one can cast a spell in anger. A cow's milk can also be made to dry up. Livestock can also die. For whatever you want, a spell can be cast. There was a woman here who cast spells. She died. It is said that sorcerers die a painful death. When she was dying, they had to take the ceiling out of the room.

The custom of taking out the ceiling over the bed of the dying sorcerer is common in Latgale as well (Lielbārdis 2008: 194-195). There are two cases in Latvian beliefs when sorcerers die, suffering seriously: 1) if they have caused harm to others, and 2) if they did not pass their knowledge to others. The taking out of the ceiling helps the soul to leave the body and is arranged only in cases of a sorcerer's death.

The word čaraunitks is also used with the same meaning. Informant Nina Kukule tells us: "A čaraunīks is the same thing. Someone who casts spells. Who casts spells to make people sick. They do evil things." Nina Kukule tells about a witch who was not able to die, and this is why the ceiling was taken from her room and a stake of aspen was poked into the ground next to the cross on her grave, with its branches facing downwards. Nina Kukule also told about sorcerers who were able to transform themselves into a pig or a cart wheel:

I don't know, perhaps we were lied to and we are passing on the lie. Some people were sorcerers. A pair of young people were walking along the road. A pig followed them everywhere. They had to keep running away. Some brave people got together and shot the pig in the ear. In the morning the neighbours came to visit and asked: "Where is your mother?" - "She's 
sleeping," they answered. - "What's wrong with her?" - "She doesn't feel well, she's sick. Her head is aching; it's wrapped in this here cloth. She's sleeping." See, how the lads shot her in the ear!

A similar story is told about a cart wheel. This kind of story about a sorcerer's power to transform into a wheel or a pig is also familiar in the regions close to Timofeyevka, except that a witch is mentioned in these stories (Fursova 2003: 62). However, this similarity does not necessarily indicate a direct link with Latvian folklore, considering that this Siberian region is inhabited mainly by the descendants of immigrants from the western provinces of the Russian empire, and not just Latvians.

Stories about people with the evil eye are also encountered in Timofeyevka. Latvian beliefs suggest that people or livestock can be harmed by the evil eye (nobrīnit) by complimenting them: "You should never say: 'They are so beautiful!' about calves, or about flowers or crops. You can put a curse on them" (Šmits 1940-1941: 21854). The experience of Nina Kukule affirms the presence of this assumption in Timofeyevka as well: "The evil eye can put a curse on you. When I was little, I often had the evil eye cast on me." In the informant's youth, she had been laying tables for a wake, when her mother-in-law had seen her and said: "Look how strong you are, you can do everything!" And then she became sick. Her mother-in-law had said: "I hate Nina, I cast an evil eye on her!" She brought a lady who said an incantation for Nina and washed her. The informant Vala Savenko explained that people who have the evil eye are those people who, as babies, had already been weaned from the breast, but began breastfeeding again some time later. In Latgale these children were called apziejdiets (Ulanowska 1891: 207; Muktupāvela 2006: 82-92).

\section{CONCLUSIONS}

Returning to the relationship between magic and religion, as was mentioned previously, according to Marcel Mauss (2006 [1972]: 30), magic or magical activities are private, secret, mystical, and forbidden actions, which are not part of officially recognised cult practice. In this case, the term magic should be understood as wrong, actions that stand in opposition to the tenets of Catholicism. But in the case of Timofeyevka, it is more problematic to share the position of representatives of the Catholic Church. The common view of society was different because there had been no priests as the church had been destroyed in the early childhood of most informants. Therefore, a dialogue between the Church and Timofeyevka's society had not existed in the past 70 years. Despite 
this, the presence of Catholic customs is notable in the worldview of the older generation. For example, when going to bed, Valia Savenko crosses the corners of the room, so that nothing bad would happen while she is asleep, and says the Lord's Prayer. She also crosses the doors on Epiphany to protect her livestock. In turn, the healing of people and livestock with charms, hymns, or prayers is not approved by the representatives of the Catholic Church in Latvia, but the practice still exists.

According to the classifications suggested by Kārlis Straubergs, magic involves the activities of healers, sorcerers and cartomancers, both in real practice and in beliefs and stories of personal experience. With respect to today's Latvia, magic would also include the actions that were performed in Timofeyevka to conjure rain, because such a practice does not exist anymore. Vera Loča tells us:

One year it did not rain for a long time. Then the women took this icon we have here, of Saint Anthony. Then we started to walk around the village with these icons. In the evening, rain clouds began to appear. And in the morning it was already raining. That was a long time ago. Before the war. No, during the war.

Vera Savenko also remembers that there was a large icon that was carried around a burning building in order to put out a fire, and also in case one had started.

These customs - the healing of people and livestock with prayers, Catholic hymns and charms to prevent diseases, fire or drought by icons of saints - established by Catholics in medieval times (including the activities of religious orders, for example, Jesuits), are no longer practised in Latvia today, although they have been preserved in Timofeyevka and were still maintained during the Second World War. Over time these activities have transformed from an official custom into an informal practice, which can be defined as magic. Therefore it is not possible to draw a strict division between religion and magic in the experience of Latvians in Timofeyevka. Straubergs also reached the same conclusion when considering the interrelationship between religion and magic in Latvians' experience in Latvia: "Wherever there is religion, there is magic, the signs of which become ever more similar: a belief in supernatural powers, which people are able to use" (Straubergs 1923: 805). The division only exists when one of these is considered to be a higher cultural construct, although with this approach we return to the late 19th century discussion about magic and the understanding of religion. The community has been creating a religion of its own since the 1930s, when the church was closed down in Timofeyevka, by repeating the stories that had already been heard, and experiencing new ones, in this way gaining validation for their own worldview. 
One can observe opposing tendencies in the preservation and functioning of traditional cultural material in Timofeyevka and other Siberian Latvian villages - congelation and convergence. Isolation and the emphasis of difference from other local communities (denominational and language-based) help to defend traditions from outside influences, for some time. On the other hand, economic, political or other types of contacts are prerequisites for a minority culture to merge with the landscape of the era and the place - both Soviet and Slavic traditions. If this contact is intense, then the unification of culture will be faster. Language and a broad range of inherited traditions have been preserved in Timofeyevka due to the location of the village: it is situated away from large cities and main roads. In turn, by merging with similar Slavic traditions, some customs have still been maintained in active use, although in a slightly different form, for example, in Easter, Pentecost and Midsummer celebrations.

However, the question remains about the influence of Slavic (Russian, Byelorussian and Polish) culture in Latgale prior to the time that the settlers of Timofeyevka left Latvia, and its influence on the following generations when they had already settled down in Siberia. The evaluation of this question is hindered by the fact that Latvians in Timofeyevka (the same as in Latgale) have lived side by side with the Slavs. Polish settlers also lived in the area around the village, and were regarded as more similar to Latvians than Russians, and were better accepted in Timofeyevka because of their Catholicism.

Timofeyevka's seasonal and family customs as well as belief legends and stories of personal experience demonstrate that these can be included in the sum total of Latvian customs and traditions, with a narrower localisation - Latgale, as can also certain aspects borrowed from Slavic culture. The simplification of tradition occurs both in Latvia and Timofeyevka, although the community in Timofeyevka has been successful in preserving particular traditions or their features, which have disappeared much sooner in the Latvian experience: for example, riding horses at Shrovetide. New variations of traditions have also been created: for example, smoking out a grave with the pages of a prayer book.

The Latvian community in Timofeyevka has knowledge of the divine, which manifests itself in various traditional situations. Seasonal celebrations, family rituals and also daily celebrations can be related to both religion and magic, which are tightly interwoven to create one overarching conceptual system. When examining the traditional heritage of Timofeyevka in the context of other Siberian Latvian villages, it stands out as being one of the richest. 


\section{ACKNOWLEDGEMENTS}

This article has been elaborated by support of the European Social Fund within the project "Cultures within a Culture: Politics and Poetics of Border Narratives”, No. 1DP/1.1.1.2.0/13/APIA/VIAA/042.

\section{NOTES}

1 The main traits distinguishing Latgalians from Latvians are the language (High Latvian dialect) and religion (Catholicism). In the recent Russian census Latgalians and Latvians were still shown as different nations. In this article the author uses the terms Latvians and Latgalians as synonyms, including the Latvians of Timofeyevka, with their adherence to Catholicism and their language based on the High Latvian dialect, which is a dialect of the Latvian language.

2 The Office of the Dead is a tradition of a musical performance, which is linked to funerals and the remembrance of the deceased on certain subsequent days, as well as to annual family events dedicated to the departed. The tradition has been widespread mainly in the Latvian Catholic community in Latgale, the eastern part of Latvia, since the end of the 18th century, and continues to be practised today.

\section{MANUSCRIPT SOURCES}

Fieldwork materials from 2004 and 2006 in possession of the author.

\section{REFERENCES}

Boiko, Mārtiṇš 2002. Tikšanās ar mirušajiem sapṇos: tipizēti un netipizēti stāstījumi un to funkcionālie un kultūrvēsturiskie konteksti. [Meeting with the Dead in Dreams: Typical and Non-Typical Stories and Their Cultural-Historical Contexts.] In: Agita Lūse (ed.) Cilvēks. Dzīve. Stāstījums. [Man. Life. Narrative.] Rīga: LU Literatūras, folkloras un mākslas institūts \& Latvijas antropologu biedrība, pp. 115-125.

Brolišs, Jāzeps 2000. Latgales latviešu likten,i Sibīijīā. [Latgalian Fates in Siberia.] Rēzekne: Latgales kultūras centra izdevniecība.

Čudare-Erina, Broṇislava 2005. Svētki un svinamās dienas Latgalē. [Festivities and Holidays in Latgale.] In: Inese Paklone (ed.) Nomales identitātei. [To the Identity of Outskirts.] Rīga: Madris, pp. 141-209.

Fursova, Elena 2003. Kalendarnye obychai i obriady vostochnoslavianskikh narodov Novosibirskoi oblasti kak rezul'tat mezhetnicheskogo vzaimodeistviia. [Calendar Rites and Rituals of East Slavic Peoples of Novosibirsk Oblast as a Result of Interactions.] Part 2. Obychai i obriady letne-osennego perioda. [Customs and 
Rituals of the Summer-Autumn Period.] Novosibirsk: Institut arkheologii i etnografii SO RAN.

Jansons, Jānis Alberts 1937. Maǵija latviešu tautas tradīcijās. [Magic in Latvian Folk Traditions.] Rīga: Valters un Rapa.

Jansons, Jānis Alberts 2010. Latviešu masku gājieni. [Latvian Mask Processions.] Rīga: Zinātne.

Jurevičs, Ontons \& Meikšans, Jezups 1933. Bazneicu puorverssim par kuḷturas neseju. [Let's Turn the Church into a Culture Bearer.] Newspaper Taisneiba, No. 56, June 26, p. 4. Available at http://www.periodika.lv/periodika2-viewer/view/indexdev.html\#panel:pp | issue:/p_001_taip1933n056| article:DIVL171|issueType:P, last accessed on July 2, 2014.

Kīlis, Roberts 2002. Nodomu valoda: atbildība un vainošana Babraukas ciema iemītnieku stāstos. [The Intent Language: Responsibility and Blame in the Stories of Inhabitants of Babrauka Village.] In: Agita Lūse (ed.) Cilvēks. Dzīve. Stāstījums. [Man. Life. Narrative.] Rīga: LU Literatūras, folkloras un mākslas institūts \& Latvijas antropologu biedrība, pp. 81-94.

Kolotkin, Mikhail 2012. Latgal'skie poselentsy v Sibiri. [Latgalian Immigrants in Siberia.] Achinsk \& Sankt-Peterburg: Filologicheskii fakul'tet SPbGU.

Krasnais, Vilberts 1938. Latviešu kolonijas. [Latvian Colonies.] Rīga: Latvju Nacionālās Jaunatnes Savienības izdevums.

Līdeks, Osvalds 1991. Latviešu svētki. Latviešu svinamās dienas. [Latvian Festivities. Latvian Holidays.] Rīga: Scientia.

Lielbārdis, Aigars 2007. Kalendārie svētki Sibīrijas latviešu un latgaliešu ciemos. [Calendar Celebrations in Latvian Villages in Siberia.] In: Baiba KrogzemeMosgorda (ed.) Meklējumi un atradumi. [Searches and Findings.] Rīga: Zinātne, pp. $156-175$.

Lielbārdis, Aigars 2008. Vārdošanas tradīcijas Vārkavā. [Charming Traditions in Vārkava.] In: Janīna Kursīte \& Jolanta Stauga (ed.) Vārkava: Tradicionālā kultūra un mūsdienas. [Vārkava: Traditional Culture and Today.] Rīga: Madris, pp. 192-206.

Lielbārdis, Aigars 2011. Latvieši latviešu acīm: Sibīrija. Timofejevka = Latvians about Latvians: Siberia. Timofeyevka. Rīga: Latvijas Universitātes Literatūras, folkloras un mākslas institūts.

Lielbārdis, Aigars \& Boiko, Mārtiṇš 2012. Psalmu dziedāšana Latgalē. Officium defunctorum $=$ The Office of the Dead in Latgale. Rīga: LU Literatūras, folkloras un mākslas institūts.

Lotkin, Ilia 1996. Sovremennye etnicheskie protsessy u latyshei i estontsev Zapadnoi Sibiri. [Contemporary Ethnic Processes of Latvians and Estonians in Western Siberia.] Moskva: Institut etnologii i antropologii im. N. N. Miklukho-Maklaia.

Mauss, Marcel 2006 [1972]. A General Theory of Magic. London \& New York: Routledge. Melnalksnis, Augusts 1933. Kolonijas, latviešu. [Colonies, Latvian.] In: Arveds Švābe \& Aleksandrs Būmanis \& Kārlis Dišlērs (eds.) Latviešu konversācijas vārdnīca. [Latvian Conversation Vocabulary.] Vol. 9. Rīga: A. Gulbja apgāds, col. 17113-17142.

Melnalksnis, Augusts 1938. Sibīrija. [Siberia.] In: Vilberts Krasnais. Latviešu kolonijas. [Latvian Colonies.] Rīga: Latvju Nacionālās Jaunatnes Savienības izdevums, pp. 286-342. 
Mežs, Ilmārs 2011. Statistiskās ziṇas par Sibīrijas latgaliešiem: Timofejevkas etnodemogrāfiskais apskats. [Statistical Information about Latgalians in Siberia: An Ethno-Demographic Survey of Timofeyevka.] In: Aigars Lielbārdis (ed.) Latvieši latviešu acīm: Sibīrija. Timofejevka = Latvians about Latvians: Siberia. Timofeyevka. Rīga: Latvijas Universitātes Literatūras, folkloras un mākslas institūts, pp. 69-81.

Muktupāvela, Rūta 2006. Atzīdeṇa fenomens latviešu un lietuviešu tradicionālajā kultūrā. [Phenomenon 'Atzīdenis' in Latvian and Lithuanian Traditional Culture.] Karogs, Vol. 4, pp. 82-92.

Reidzāne, Beatrise 2008. Latviešu svētku un svinamo dienu nosaukumu etimoloǵijas, to problemātika. [Etymologies of Latvian Festivities and Holidays: Problems.] Letonica, Vol. 18, pp. 232-246.

Salve, Kristi 1994. Lībiešu tautas kalendārs. [Livonian Folk Calendar.] In: Kersti Boiko (ed.) Lībieši. [Livonians.] Rīga: Zinātne, pp. 160-179.

Šḳilters, Kārlis 1928. Latkoloniju vēsture. [History of Latvian Colonies.] Maskava: Prometejs.

Skobajs, Piters 1928. Nabadzeiba organizejas un imovia tuklus bogotnikus. [Poverty Organised and Limited the Money-Bags.] Newspaper Taisneiba, No. 43, November 23, p. 2. Available at http://www.periodika.lv/periodika2-viewer/view/indexdev.html\#panel:pp| issue:/p_001_taip1928n43 | article:DIVL48 | issueType:P, last accessed on July 2, 2014.

Skrinda, Kazimirs 1910. Weiskupa ceľ̦s pa Sibiri. [Bishop's Path through Siberia.] Newspaper Drywa, No. 35, January 26, p. 4. Available at http://data.lnb.lv/nba01/ Drywa/1910/Drywa1910-035.pdf, last accessed on June 12, 2014.

Šmits, Pēteris 1940-1941. Latviešu tautas ticējumi. [Latvian Folk Beliefs.] Vols. 1-4, Rīga: Latviešu folkloras krātuve.

Straubergs, Kārlis 1923. Piezīmes pie dažām latviešu burvju grāmatām. [Remarks on Some Latvian Sorcery Books.] Izglïtżbas Ministrijas Mēnešraksts, No. 7, July 1, pp. 804-816. Available at http://www.periodika.lv/periodika2-viewer/view/index-dev. html\#panel:pp|issue:/p_001_izmm1923n7| page:58|issueType:P, last accessed on July 2, 2014.

Straubergs, Kārlis 1935-1936. Maǵija. [Magic.] In: Arveds Švābe \& Aleksandrs Būmanis \& Kārlis Dišlērs (eds.) Latviešu konversācijas vārdnīca. [Latvian Conversation Vocabulary.] Vol. 13. Rīga: A. Gulbja apgāds, col. 25146-25250.

Strautniece, Vaira 1995. Lejas Bulāna-latviešu ciems Sibīrijāa. [Lejas Bulāna: A Latvian Village in Siberia.] Rīga: Zvaigzne ABC.

Tihovskis, Heronīms 1993. Kāzu paražas Latgalē. [Wedding Customs in Latgale]. Rīga: Zinātne.

Ulanowska, Stefanija 1891. Łotysze Inflant polskich. [Latvians of Polish Livonia.] In: Zbiór wiadomości do antropologii krajowej. [Collection of News in Regional Anthropology.] Vol. 15. Krakow: Akademia Umiejętności, pp. 181-282. Available at http://dlibra.umcs.lublin.pl/dlibra/docmetadata?id=1707\&from=publication, last accessed on June 13, 2014. 
Zēvers, Jānis 1925. Kāds 150 gadus vecs, līdz šim nepazīstams katḳisms latgaliešu izloksnē. [A 150-Year-Old and Unknown Catechism in Latgalian Dialect.] Izglītības Ministrijas Mēnešraksts, No. 6, June 1, pp. 601-609. Available at http://www. periodika.lv/periodika2-viewer/view/index-dev.html\#panel:pp|issue:/p_001_iz mm1925n6 | article:DIVL121 | page:43 | block:P43_TB00002| issueType:P, last accessed on July 2, 2014. 